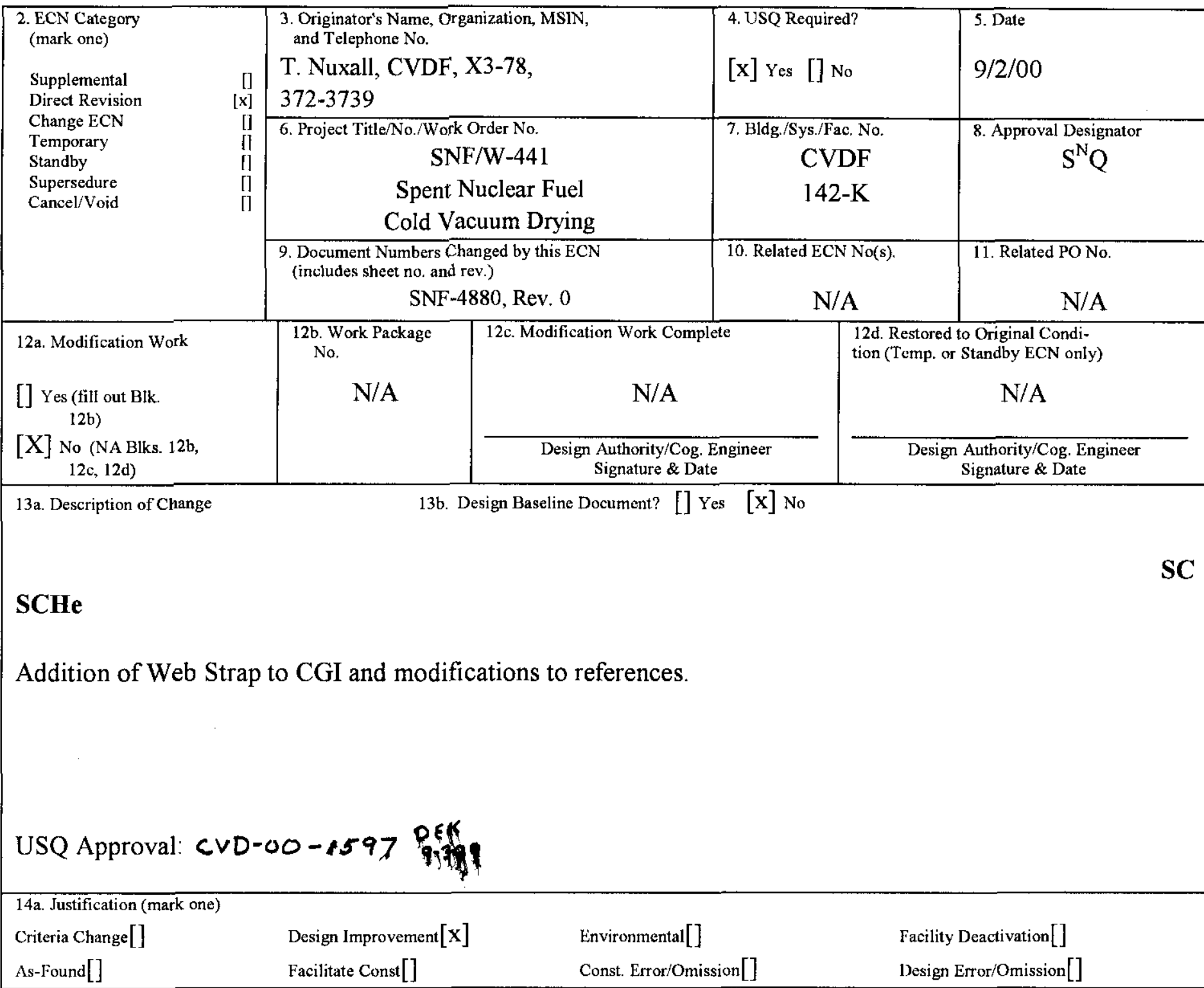

14b. Justification Details

Provides additional support for SCHe Bottles. Updated references to reflect current documentation.

The design verification method for SS/SC components is by independent review in accordance with EN-6-027-01.

Documentation of this review is accomplished by the independent reviewer approval signature on page 2 of this ECN.

15. Distribution (include name, MSIN, and no. of copies)

See distribution sheet.

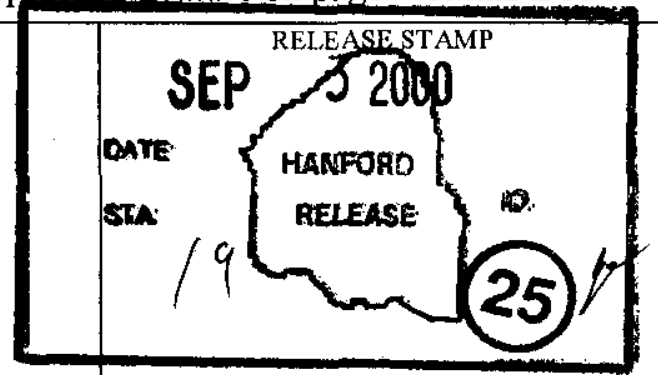




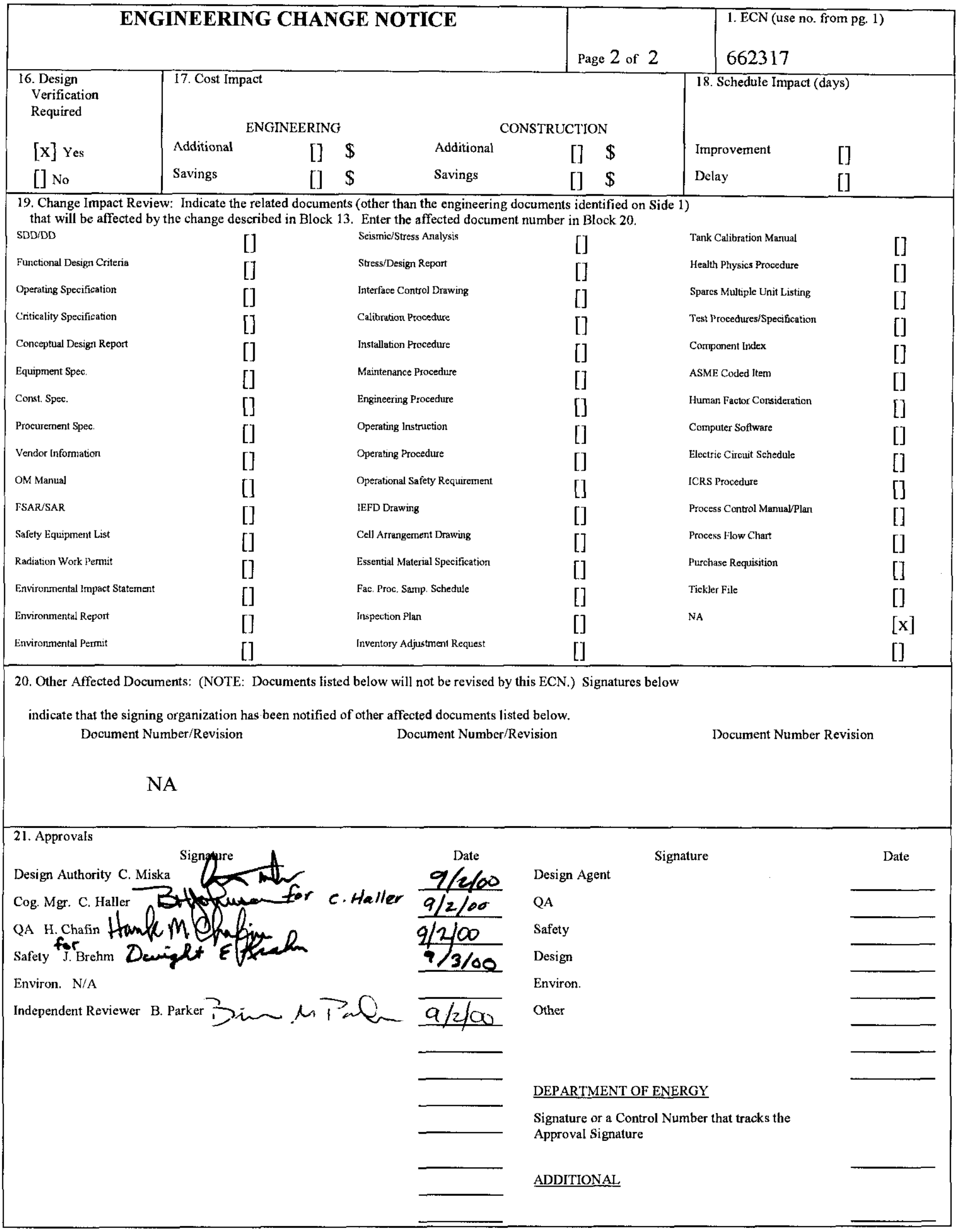


SNF-4880

Revision 1

\section{Seismic Restraint Cable and Web Strap for SCHe Helium Bottles}

Prepared for the U.S. Department of Energy

Assistant Secretary for Environmental Management

Project Hanford Management Contractor for the

U.S. Department of Energy under Contract DE-AC06-96RL13200

Fluor Hanford

P.O. Box 1000

Richland, Washington 


\title{
Seismic Restraint Cable and Web Strap for SCHe Helium Bottles
}

\author{
Project No: W-441 \\ Document Type: RPT \\ Division: SNF \\ C Miska \\ $\mathrm{FH}$
}

Date Published

September 2000

Prepared for the U.S. Department of Energy

Assistant Secretary for Environmental Management

Project Hanford Management Contractor for the

U.S. Department of Energy under Contract DE-AC06-96RL13200

\section{Fluor Hanford}

P.O. Box 1000

Richland, Washington
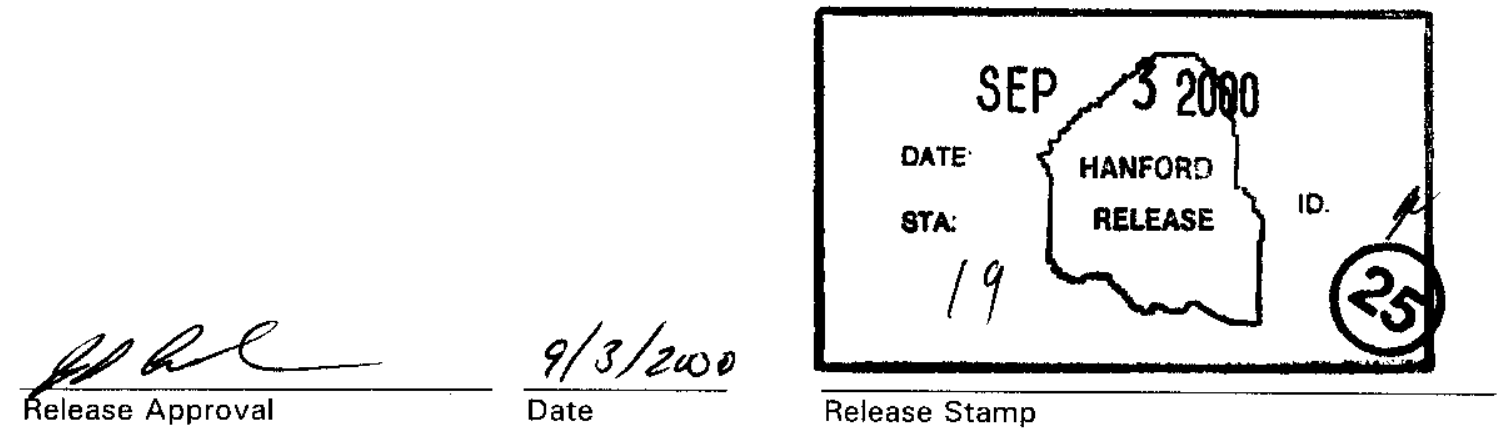
SNF-4880

Revision 1

TRADEMARK DISCLAIMER

Reference herein to any specific commercial product, process,

or service by trade name, trademark, manufacturer, or

otherwise, does not necessarily constitute or imply its

endorsement, recommendation, or favoring by the United

States Government or any agency thereof or its contractors or subcontractors.

This report has been reproduced from the best available copy.

Printed in the United States of America

Total Pages:

13 


\section{RECORD OF REVISION}

SEISMIC RESTRAINT CABLE AND WEB STRAP FOR SCHE HELIUM BOTTLES

Change Control Record

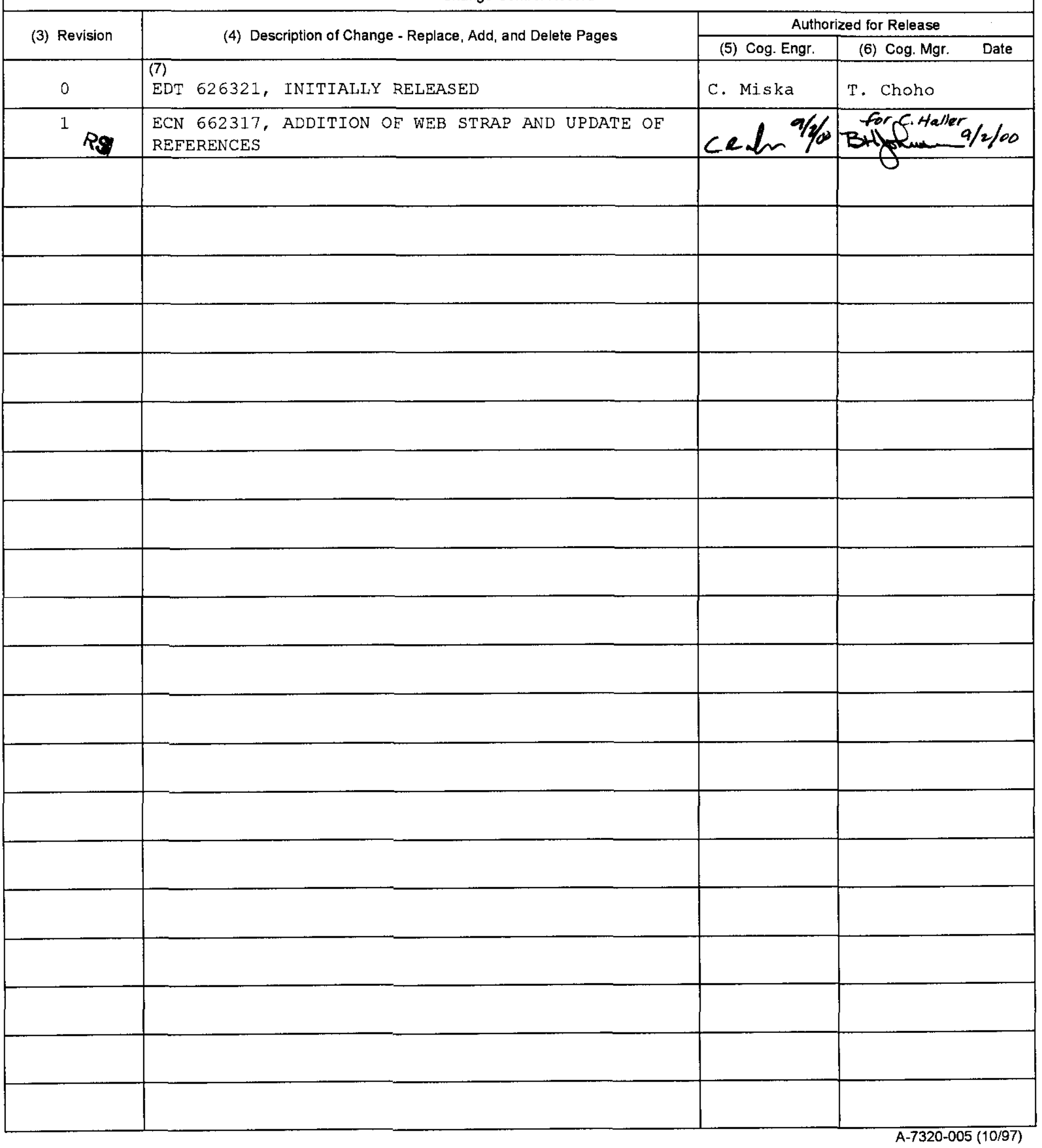


Commercial Grade Item Upgrade Dedication Form

\begin{tabular}{|l|l|}
\hline ECN No. N/A CGI No. CGI-SNF-D-13-2-P5-053 & Page 1 of 9 \\
Title: Seismic Restraint Cable and Web Strap for SCHe Helium Bottles & \\
\hline
\end{tabular}

\begin{tabular}{|c|c|c|c|c|}
\hline \multicolumn{5}{|c|}{ Secter 1 Pat Intornation } \\
\hline item & N N/A & Manufacturer: N/A & & Supplier: N/A \\
\hline \multicolumn{3}{|c|}{ Mfg. Part/Model No.: N/A } & \multicolumn{2}{|l|}{ Supplier's P/N: N/A } \\
\hline \multicolumn{5}{|c|}{ Part Description: N/A } \\
\hline \multicolumn{5}{|c|}{ End Use Description: N/A } \\
\hline \multicolumn{5}{|c|}{ Section $2 a$ Compenent Intormation. } \\
\hline & $\begin{array}{l}\text { c Restraint Cables and Web } \\
\text { for SCHe supply bottles to the } \\
\text { process system. }\end{array}$ & $\begin{array}{l}\text { Specification No.: } \\
\text { SNF-5304 } \\
\text { (W-441-P5) }\end{array}$ & $\begin{array}{l}\text { Manufacturer: } \\
\text { McMaster Carr }\end{array}$ & $\begin{array}{l}\text { Past P.O. No.: } \\
\text { N/A }\end{array}$ \\
\hline $\begin{array}{l}\text { Proc } \\
\text { Cabl } \\
8236 \\
\text { Web }\end{array}$ & $\begin{array}{l}\text { Restraint: } 30785 \text { T5 (Dwg. H-1- } \\
\text { Item 72) } \\
\text { 842T18 }\end{array}$ & $\begin{array}{l}\text { Equipment Supplier ( } \\
\text { Apollo }\end{array}$ & if different from manufacturer): & $\begin{array}{l}\text { Equip. Supplier's Part No.: } \\
\text { N/A }\end{array}$ \\
\hline \multicolumn{5}{|c|}{$\begin{array}{l}\text { Component Description: This seismic restraint cable fits the neck of the } \mathrm{SCH} \text { helium supply bottle to limit bottle motion } \\
\text { in the event of a Seismic Event. The web strap is for the seismic stand and has a ratchet tensioning buckle. }\end{array}$} \\
\hline \multicolumn{5}{|c|}{ Section $2 b$ Comnercial Avallability of the llem. } \\
\hline \multicolumn{5}{|c|}{$\begin{array}{l}\text { 1. Is the Item available from a catalogue from a qualified NQA1 supplier or ISO } 9000 \text { supplier (coordinate with project CGI } \\
\text { interface Engineer or BTR)? [ ] YES (go to \#2 below) [X] NO (go to procedure step 6.3.2, proceed to dedicate Item) } \\
\text { If not available from a qualified NQA1 supplier, is it available from an ISO } 9000 \text { supplier? (coordinate w/ project CGI } \\
\text { Interface Engineer or BTR): [ ] YES (go to \#2 below, dedicate ltem) [X] NO (dedicate Item) }\end{array}$} \\
\hline \multicolumn{5}{|c|}{ 2. List of Candidate qualified suppliers or ISO 9000 suppliers: N/A } \\
\hline \multicolumn{5}{|c|}{ 1. Recommended Procurement Strategy(coordinate with project CGl interface Engineer or BTR): N/A } \\
\hline \multicolumn{5}{|c|}{ Section 20 CG Determination. } \\
\hline \multicolumn{5}{|c|}{$\begin{array}{l}\text { \#1: Is the Item subject to design or specification requirements that are unique to nuclear facilities } \\
\text { [ ] YES (the Item is not commercial grade) } \\
\text { \#2: Is the Item used in applications other than nuclear facilities or activities? }\end{array}$} \\
\hline \multicolumn{5}{|c|}{$\begin{array}{l}\text { [ ] NO (the item is not commercial grade) } \\
\text { \#3: Is the Item ordered from manufacturer/supplier on the basis of specifications set forth in the manufacturer's catalog? } \\
{\left[\begin{array}{l}\mathrm{X} \\
\text { [ ] (the item is not commercial grade) }\end{array}\right.} \\
{[\mathrm{X}] \text { All three criteria have been satisfied. The Item meets the definition of commercial grade. }}\end{array}$} \\
\hline \multicolumn{5}{|c|}{ 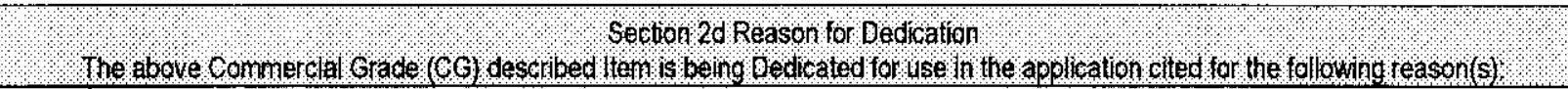 } \\
\hline \multirow[t]{5}{*}{$\mathbf{x}$} & \multicolumn{4}{|c|}{ Item is being purchased from a non-ESL manufacturer supplier as CG to be used in a Safety Class application. } \\
\hline & \multicolumn{4}{|c|}{ Item is being purchased from a non-ESL manufacturer supplier as CG to be used in a Safety Significant application. } \\
\hline & \multicolumn{4}{|c|}{ Item was purchased from a non-ESL manufacturer supplier as CG to be used in a Safety Class application. } \\
\hline & \multicolumn{4}{|c|}{ Item was purchased from a non-ESL manufacturer supplier as CG to be used in a Safety Significant application. } \\
\hline & \multicolumn{4}{|c|}{ Other ('like-for-like', similar, substitution, replacement evaluation) } \\
\hline
\end{tabular}




\section{Section 3 Fallure Effects Evaluation}

A. Part/Component Safety Function:

1. The cable provides a restraint to limit motion of the $\mathrm{SCHe}$ helium supply bottle in the event of a Seismic Event.

2. Maintain critical function before, during, and after Seismic Event

B. Part/Component Functional Mode:

\begin{tabular}{l|l|l|l|l|} 
Safety Function \#1: & & Active & $\mathbf{X}$ & Passive \\
Safety Function \#2: & & Active & $\mathbf{X}$ & Passive \\
Safety Function \#3: & & Active & & Passive \\
\hline
\end{tabular}

Active - Mechanical or Electrical change of state is required to occur for the component to perform its safety function

Passive - Change of state is not required for the component to perform its safety function

C. Host Component Safety Function (if applicable): N/A 1.

D. Failure Mode(s) and the effects on component or system safety function (see Worksheet 1);

1. Failure of the restraint cable during a Seismic Event could allow bottle displacement which may be in excess of movement experienced during the seismic testing. The effects of this condition on the SCHe supply integrity is not defined and would constitute an unreviewed safety question.

2. Damage/corrosion of the cable or web may reduce its strength to withstand the forces associated with the Seismic Event

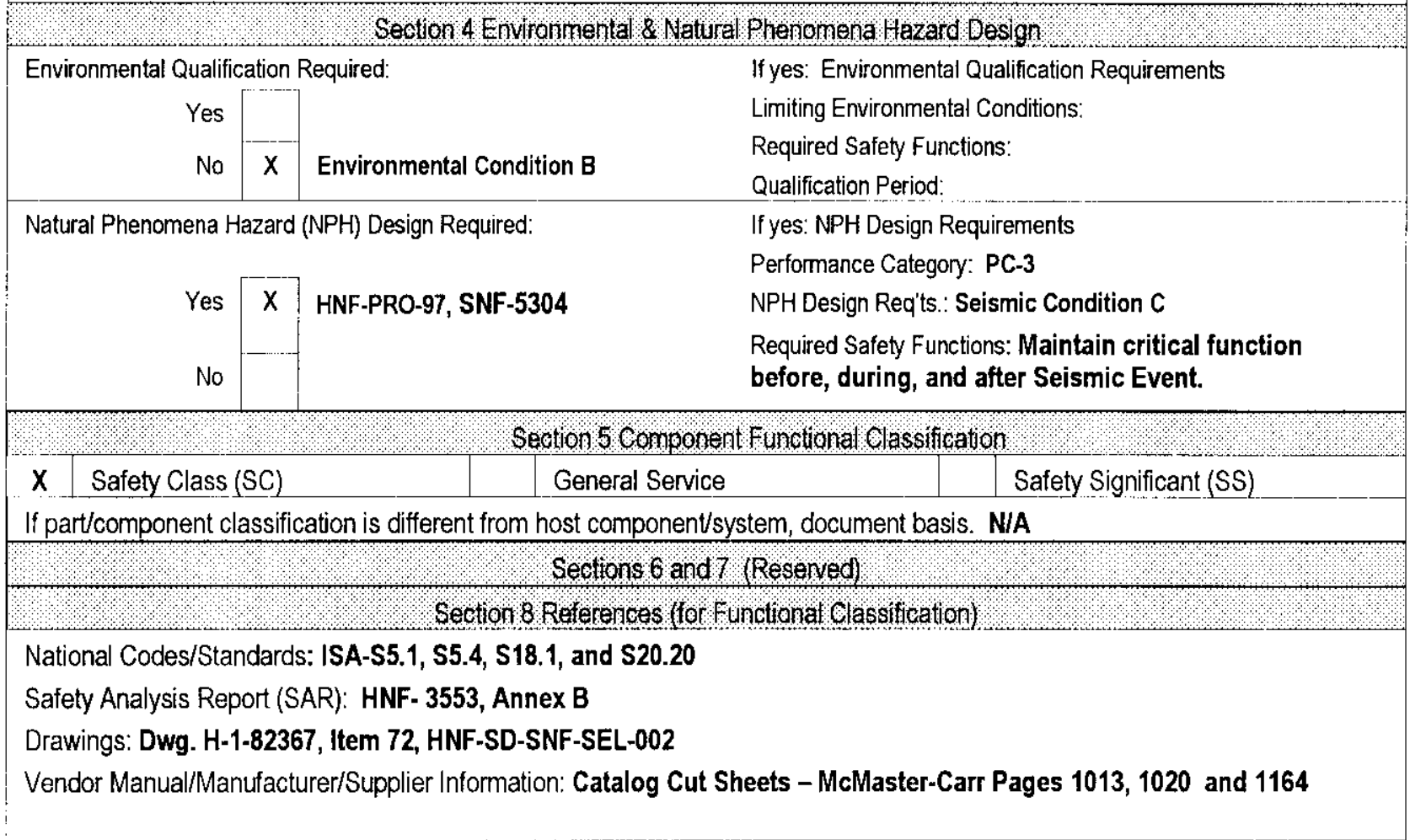


Commercial Grade Item Upgrade Dedication Form

ECN No. N/A CGI No. CGI-SNF-D-13-2-P5-053

Title Seismic Restraint Cable and Web Strap for SCHe Helium Bottles

SNF-4880, Rev. 1

Page 3 of 9

\begin{abstract}
-
\end{abstract}

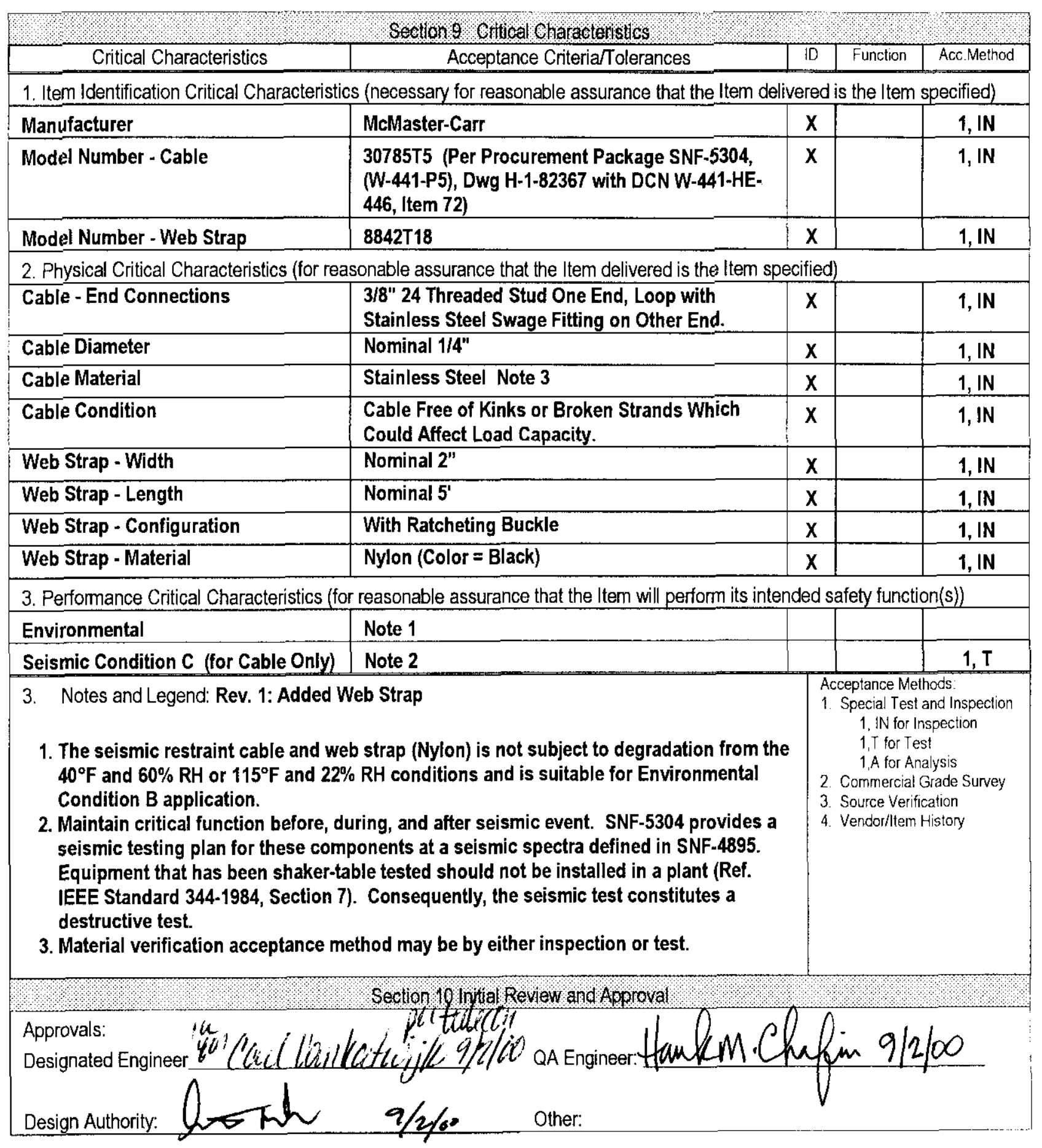


Commercial Grade Item Upgrade Dedication Form

\begin{tabular}{|l|l}
\hline ECN No. N/A & Page 4 of 9 \\
Title: Seismic Restraint Cable and Web Strap for SCHe Helium Bottles &
\end{tabular}

WORKSHEET 1

DETERMINATION OF FAILURE MECHANISMS

\begin{tabular}{|c|c|c|c|}
\hline \multicolumn{4}{|c|}{ seten } \\
\hline $\begin{array}{l}\text { Typical Failure } \\
\text { Mechanisms }\end{array}$ & Definition & \multicolumn{2}{|c|}{$\begin{array}{l}X=\text { Applicable to Component under Evaluation } \\
X ?\end{array}$} \\
\hline Fracture & $\begin{array}{l}\text { Separation of a solid accompanied by little or no } \\
\text { macroscopic plastic deformation. }\end{array}$ & $x$ & $\begin{array}{l}\text { Failure of the seismic restraint cable may permit } \\
\text { bottle movement which may be greater than } \\
\text { experienced during the seismic qualification } \\
\text { test. }\end{array}$ \\
\hline Corrosion & $\begin{array}{l}\text { The gradual deterioration of a material due to chemical } \\
\text { or electrochemical reactions, such as oxidation, between } \\
\text { the material and its environment. }\end{array}$ & & \\
\hline Erosion & $\begin{array}{l}\text { Destruction of materials by the abrasive action of moving } \\
\text { fluids, usually accelerated by the presence of solid } \\
\text { particles carried with the fluid. }\end{array}$ & & \\
\hline Open Circuit & $\begin{array}{l}\text { An electrical circuit that is unintentionally broken so that } \\
\text { there is no complete path for current flow. }\end{array}$ & & \\
\hline Short Circuit & $\begin{array}{l}\text { An abnormal connection by which an electrical current is } \\
\text { connected to ground, or to some conducting body, } \\
\text { resulting in excessive current flow. }\end{array}$ & & \\
\hline Blockage & $\begin{array}{l}\text { Clogging of a filtering medium resulting in the inability to } \\
\text { perform its purification function or blockage of flow. }\end{array}$ & & \\
\hline Seizure & $\begin{array}{l}\text { Binding of a normally moving item through excessive } \\
\text { pressure, temperature, friction, jamming. }\end{array}$ & & \\
\hline Unacceptable Vibration & $\begin{array}{l}\text { Mechanical oscillations produced are beyond the defined } \\
\text { permissible limits due to unbalancing, poor support, or } \\
\text { rotation at critical speeds. }\end{array}$ & & \\
\hline Loss of Properties & $\begin{array}{l}\text { A loss of mechanical and physical properties of a } \\
\text { material due to exposure to high temperatures, radiation } \\
\text { exposure. }\end{array}$ & & \\
\hline Excess Strain & $\begin{array}{l}\text { Under the action of excessive external forces the } \\
\text { material of the part has been deformed or distorted. }\end{array}$ & & \\
\hline Mechanical Creep & $\begin{array}{l}\text { From prolonged exposure to high temperature and } \\
\text { stress, the object will show a slow change in its physical } \\
\text { (shape and dimension) and mechanical characteristics. }\end{array}$ & & \\
\hline Ductile Fracture & $\begin{array}{l}\text { Fracture characterized by tearing of metal accompanied } \\
\text { by appreciable gross plastic deformation. }\end{array}$ & & \\
\hline \multicolumn{4}{|c|}{ 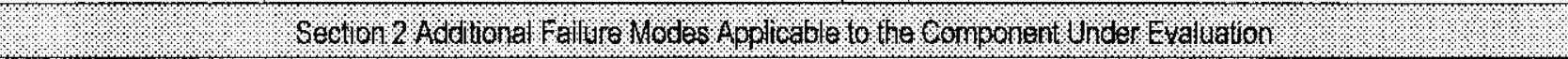 } \\
\hline \multicolumn{4}{|c|}{ 1. Damage to or deterioration of the cable and/or web with use that could reduce its strength. } \\
\hline
\end{tabular}


Checklist 1 - Acceptance Method 1 - Special Test/Inspection Verification

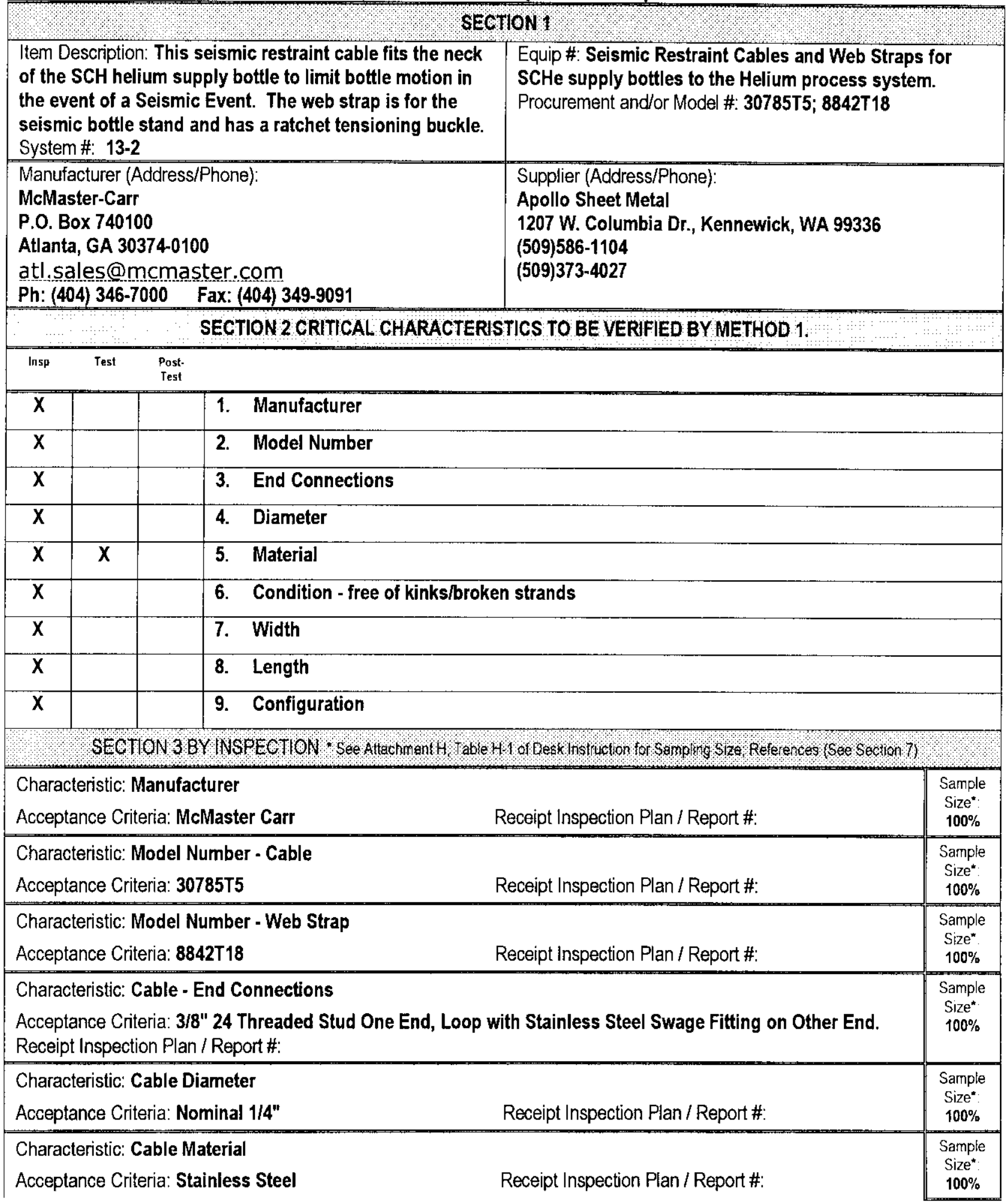


ECN No. N/A

CGI No. CGI-SNF-D-13-2-P5-053

Title: Seismic Restraint Cable and Web Strap for SCHe Helium Bottles

\begin{tabular}{|c|c|c|}
\hline \multicolumn{2}{|c|}{$\begin{array}{l}\text { Characteristic: Cable Condition } \\
\text { Acceptance Criteria: Cable Free of Kinks or Broken Strands Which Could Affect Load Capacity. } \\
\text { Receipt Inspection Plan / Report\#: }\end{array}$} & $\begin{array}{l}\text { Sample } \\
\text { Size*: } \\
100 \%\end{array}$ \\
\hline $\begin{array}{l}\text { Characteristic: Web Strap - Width } \\
\text { Acceptance Criteria: Nominal 2" }\end{array}$ & Receipt Inspection Plan / Report \#: & $\begin{array}{l}\text { Sample } \\
\text { Size*: } \\
100 \%\end{array}$ \\
\hline $\begin{array}{l}\text { Characteristic: Web Strap - Length } \\
\text { Acceptance Criteria: Nominal } \mathbf{5}^{\mathbf{1}}\end{array}$ & Receipt Inspection Plan / Report \#: & $\begin{array}{l}\text { Sample } \\
\text { Size*: } \\
100 \%\end{array}$ \\
\hline $\begin{array}{l}\text { Characteristic: Web Strap - Configuration } \\
\text { Acceptance Criteria: Strap with Ratcheting Buckle }\end{array}$ & Receipt Inspection Plan / Report \#: & $\begin{array}{l}\text { Sample } \\
\text { Size*: } \\
100 \%\end{array}$ \\
\hline $\begin{array}{l}\text { Characteristic: Web Strap - Material } \\
\text { Acceptance Criteria: Nylon (Color = Black) }\end{array}$ & Receipt Inspection Plan / Report \#: & $\begin{array}{l}\text { Sample } \\
\text { Size*: } \\
100 \%\end{array}$ \\
\hline
\end{tabular}

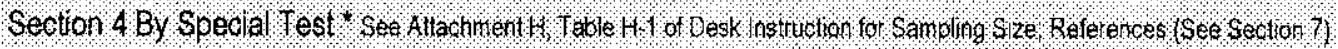

Characteristic for Test: Seismic (applies to cable restraint only)

Acceptance Criteria: Maintain Critical Function Before, During, and After Seismic Event

Sample Size: SNF-5304 provides the seismic testing plan for these components. The seismic testing is conducted for one complete panel with the components assembled on the panel and tested as a complete assembly. The test seismically qualifies the entire assembly, including mountings, piping, and components. The number of components tested is dictated by the panel assembly design.

Actual Test Value:

Test Plan and Report \#:

**If Supplier/Manufacturer or Other, Refer to CGl Checklist-2 for Support Information 


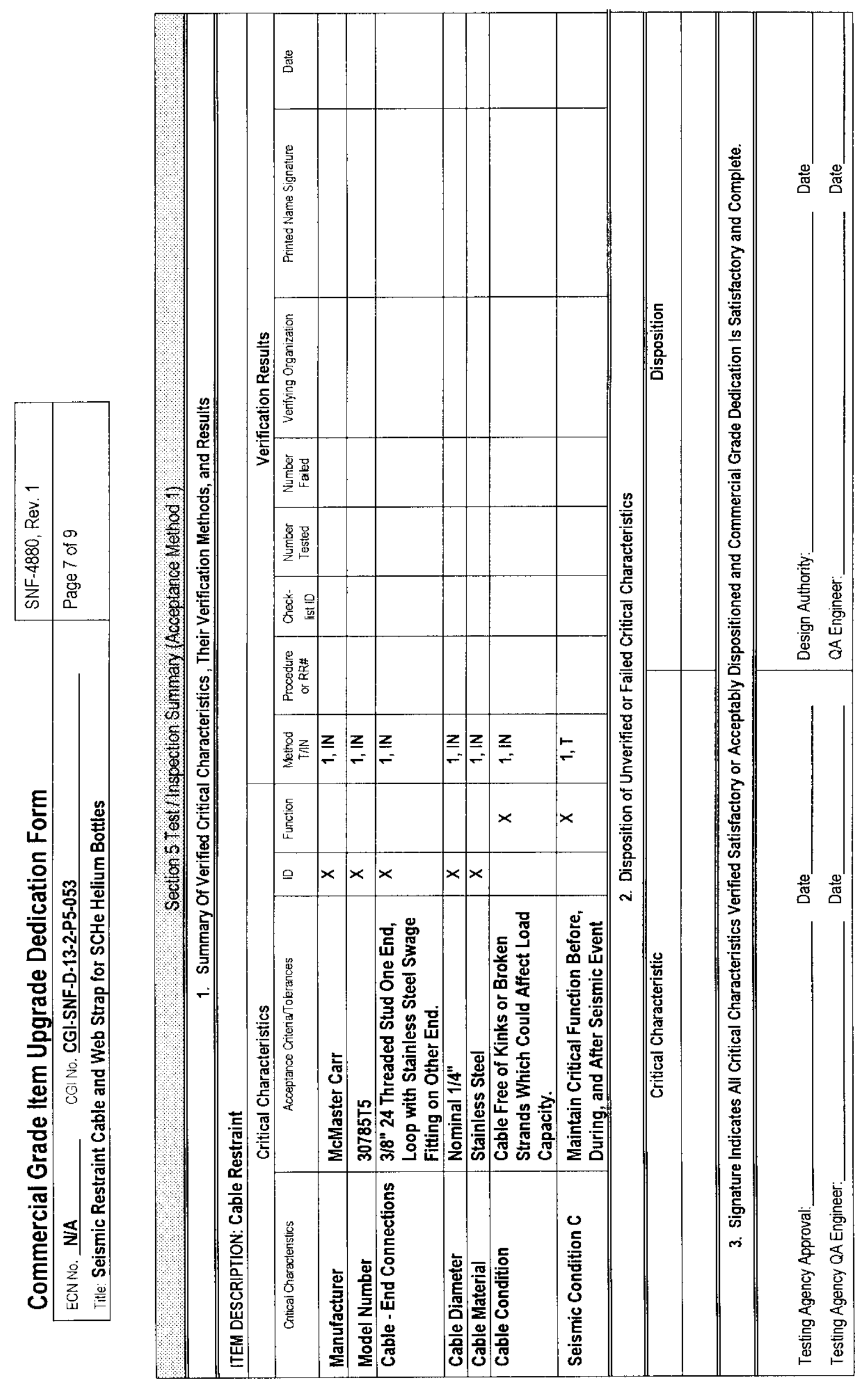




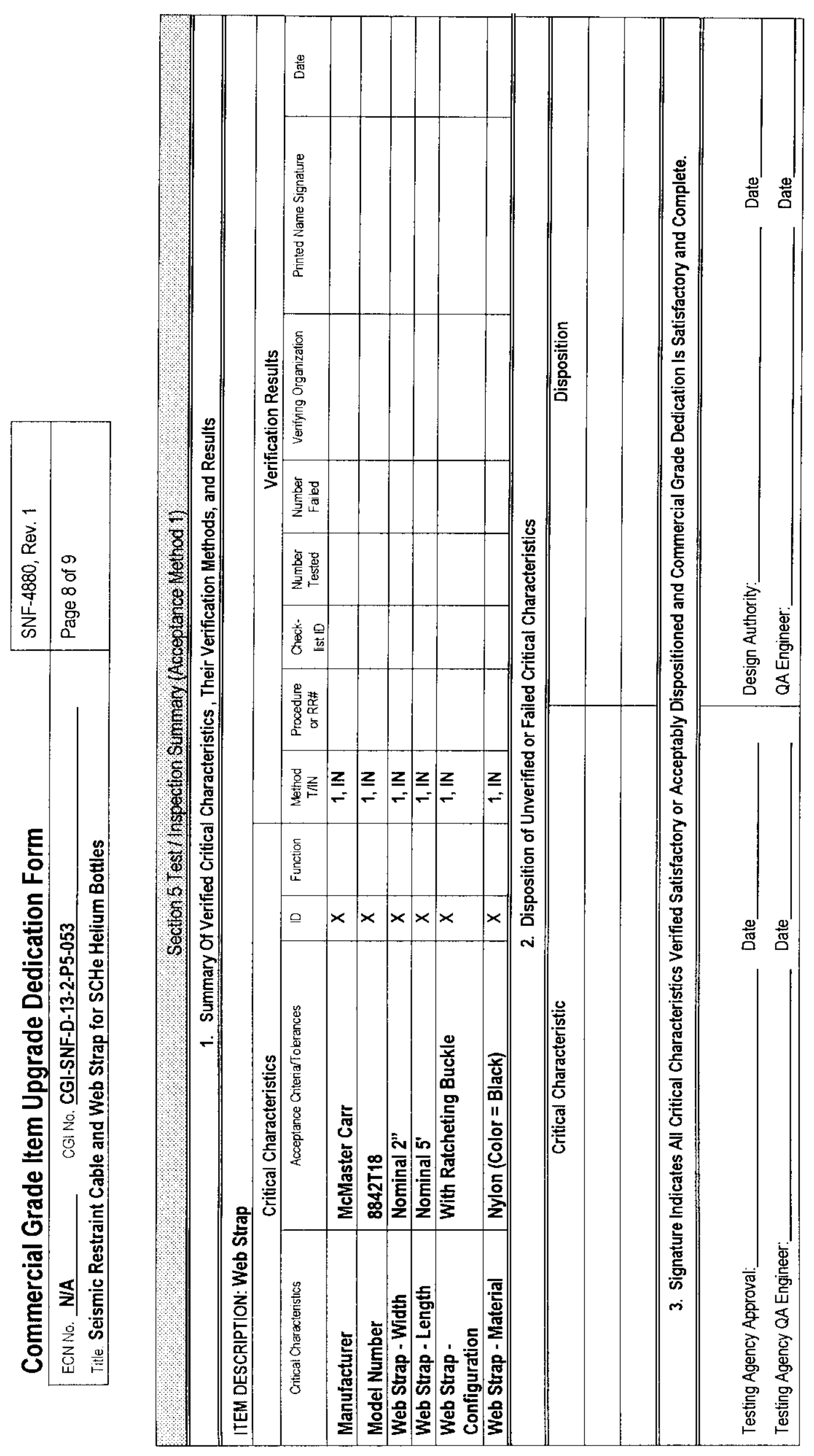


Commercial Grade Item Upgrade Dedication Form

SNF-4880, Rev. 1

ECNNo. NA

CGI No. CGI-SNF-D-13-2-P5-053

Page 9 of 9

Title: Seismic Restraint Cable and Web Strap for SCHe Helium Bottles

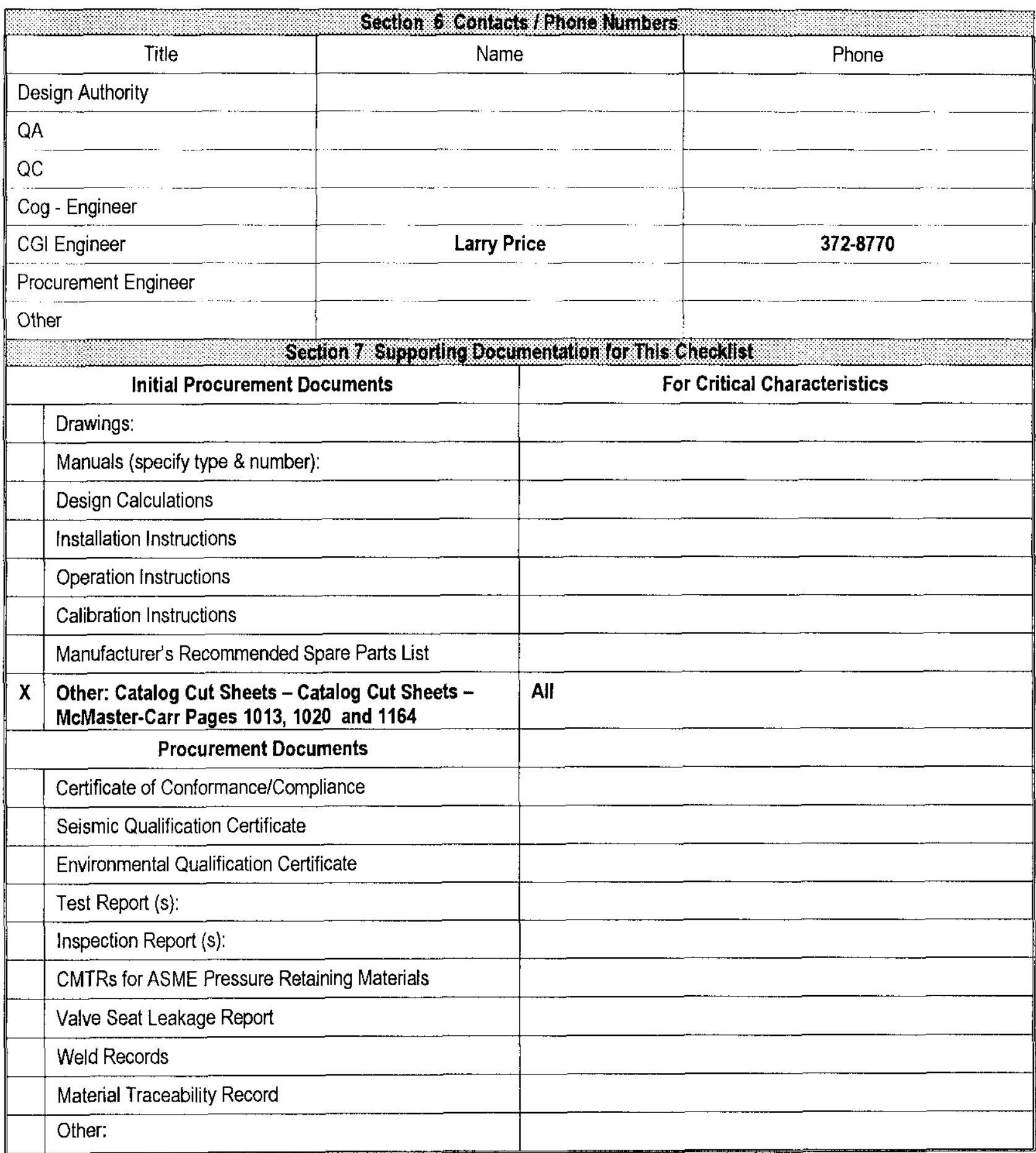


DISTRIBUTION SHEET

To

Distribution

Project Title $M$ Work Order

W-441, P5 CGI Package

Name

D. Whitehurst

G. Singh

CVD Library

R. Ramsgate

J. Brehm

P. Beaudet

P. Morrell (AVS)

C. Miska

L. Price

SNF Startup

SNE Project Files

SNE Satelite Library

C. Van Katwijk

D. Whitworth

T. Nuxall
From

SNF-CVD
Page 1 of 1
Date $9 / 2 / 00$
EDT No.
ECN No. 662317

\begin{tabular}{|c|c|c|c|c|}
\hline MSIN & $\begin{array}{c}\text { Text } \\
\text { With All } \\
\text { Attach. }\end{array}$ & Text Only & $\begin{array}{l}\text { Attach.I } \\
\text { Appendix } \\
\text { Only }\end{array}$ & $\begin{array}{c}\text { EDT/ECN } \\
\text { Only }\end{array}$ \\
\hline
\end{tabular}

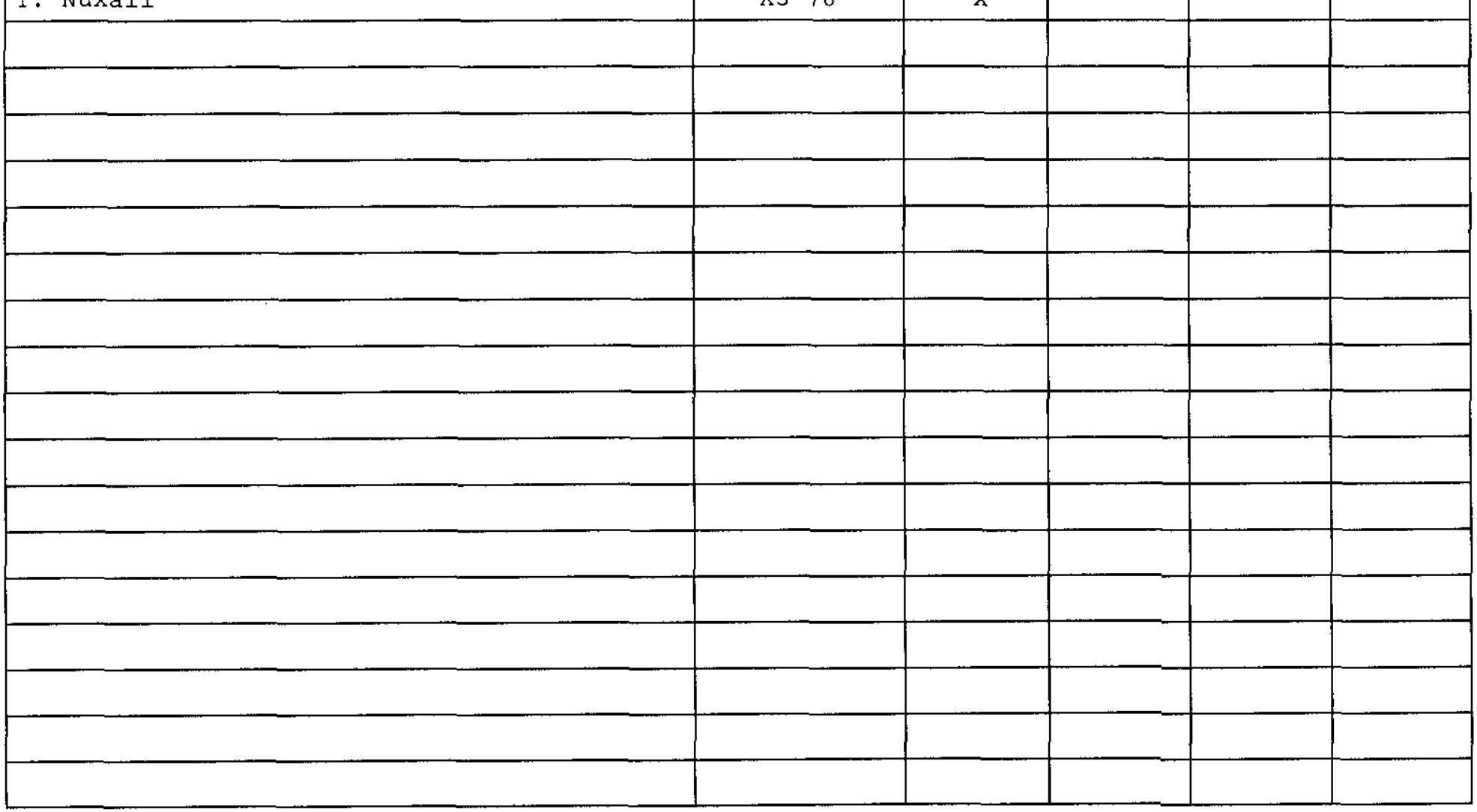

